\title{
Tax Amnesty as a Control Variable Affects The Relationship between Domestic Institutional Shareholders and the Firm Value.
}

\author{
Muhammad Rifky Santoso, Azhar Maksum, Ramli, Rina Br. Bukit \\ $\{* m . r i f k y . s a n t o s o @ g m a i l . c o m\}$ \\ Economics and Business Faculty, Universitas Sumatera Utara, Jl. Prof. T.M Hanafiah, SH, Kampus \\ USU, Medan
}

\begin{abstract}
The number of shares owned by the domestic institutional shareholders influences the firm value. The next question is whether this relationship is linear or nonlinear. When the tax amnesty policy enacted, management will adjust the strategies that influence on the firm value. The tax amnesty policy also influences the relationship between the domestic institutional shareholders and the firm value. By using the manufacturing firm listed in the Indonesia Stock Exchange, the comparative casual method, and the tax amnesty policy as a control variable, this study find out that the relationship between the domestic institutional shareholders and the firm value is nonlinear and inverted U-shaped, both with and without the tax amnesty policy. When using the tax amnesty policy as a control variable, the relationship between the domestic institutional shareholders and the firm value is getting weaker. It is estimated that this weakening is a management reaction to the tax amnesty policy whose influence is more significant compared to the influence of the domestic institutional shareholders on the firm value.
\end{abstract}

Keywords: domestic instituional shareholders, tax amenesty, control variable, nonlinear.

\section{Introduction}

One of the objectives of the company is to increase shareholder wealth. The increasing operational activity of the company, the shareholders hire an agent to manage the company properly [1]. In fact, shareholders and agents have different goals on the company; consequently, there is an agency problem to solve. One way to solve this problem is the shareholders have to monitor the management activity. When the portion of share ownership of the shareholders is small, the ability to monitor is still weak and finally has little effect on the firm value. The relationship between the portion of share ownership and the firm value is the relation based on structure [2], [3]. The change of the portion of share ownership influences the firm value. The lower the firm value, it will increase the portion of share owned [4]. The amount of the share ownership can affect the firm value differently, because the portion of share ownership can influence to the management and finally to the firm value [5][6].

Each type of shareholder has its own characteristics in influencing the firm value. The domestic institutional shareholders as investors play an important role in the financial market [7], therefore, the domestic institutional shareholders have more influence on the firm value 
that listed company than other type of shareholders. The domestic institutional shareholders have advantages compared to the foreign institutional shareholders, because the domestic institutional shareholders are better at monitoring company activities [3]. The good monitoring will certainly reduce agency costs and will positively influence the firm value.

The previous articles explain that the greater portion of share ownership by the domestic institutional shareholders will have a positive influence on the firm value [3], [7]-[9]; however; this influence is not always linear. Lozano et.al (2016) explains that the relationship between the shareholders and the firm value is non linear and U-shaped [10]. In their article, Lozano et.al (2016) define the shareholders not specifically as the domestic institutional shareholders, but include family shareholders and control shareholders. Lozano et.al (2016) use the company data in the Worldscope database. Article written by Wang (2018) explains that the relationship between the shareholders and the firm value is not linear and U-Shaped [4]. Wang (2018) defines shareholders as local government shareholders and central government shareholders in the companies listed in China.

Under a certain condition, the government needs additional revenues from taxes. One of the policies to increase tax revenues quickly is to implement a tax amnesty policy [11], and this policy finally asks the taxpayers more transparent in their tax returns. This tax amnesty policy can or cannot influence the relationship between the shareholders and the firm value. The shareholder can or cannot influence the management in participating in the tax amnesty policy and finally affect the firm value. The previous research explains that the value of the companies participating in the tax amnesty policy have reduced [12]. This paper explains the different aspect as explained by Pratama (2019). This paper explains and compares the influence of the relationship between the domestic institutional shareholders and the firm value, with or without the tax amnesty policy as a control variable.

This paper finds out that the relationship between the domestic institutional shareholders and the firm value is not linear, inverted U-shaped, either with or without the tax amnesty policy as a control variable. The relationship between the domestic institutional shareholders and the firm value is more significant and stronger when there is without the tax amnesty policy compared to implementing the policy. The tax amnesty policy has a positive and significant influence to the firm value.

\section{Method}

This paper uses the comparative casual method. This research explains and compares the relationship between the domestic instituional shareholders and the firm value, with or without the tax amnesty policy as a control variable. The previous papers explain that the domestic instituional shareholders influence positively and signifcantly to the firm value [3], [4], [7]. By linking researches conducted by Lozano et.al and Wang [4], [10], it appears that the greater the portion of share ownership, the greater the firm value, because its realation is U-shaped. This research uses the different shareholder measurements than those used by Lozano et.al and Wang, thus the hypothesis of this study are:

H1 : the domestic institutional shareholders influence the firm value.

H1.a : the relationship between the domestic instituional shareholders and the firm value is not linear. 
The tax amnesty policy enacted by the goverment influences the tax planning strategy in a company or a taxpayer [11]. The taxpayer will try to reduce the total tax payments [13] even though formally there are the additional tax payments for participating in the tax amnesty policy. The participating in the tax amnesty program by the firm is actually a management strategy, therefore, the shareholders can influence the management in the program. This paper explains how the tax amnesty policy influences the relationship between the domestic institutional shareholders and the firm value. For this reason, the hypothesis are:

H2 : the domestic institutional shareholders influence the firm value with the tax amnesty policy as a control variable.

Based on the papers written by Lozano et.al and Wang, this paper further examines whether the relationship between the domestic institutional shareholders and the firm value is consistent or inconsistent with the tax amnesty policy as a control variable, therefore, the hypothesis is:

H2.a : the relationship between the domestic institutional shareholders and the firm value is not consistent with the tax amnesty policy as a variable control.

This study uses Tobin Q formula to measure the firm value, and this formula is used by some previous papers [14], [15]. The measurement of the domestic institutional shareholders is the same as used by Thanatawee (2014) [3]. The control variables used in this paper are the same as used in the previous papers, such as size used by Ayers et.al (2018) [16], as leverage used by Klassen et.al [17], and as EPS modified from price used by Balakrishnan et.al (2017) [18]. The measuremant of the variables used in this study are in Table 1.

Table 1. Variable Measurement

\begin{tabular}{|c|c|c|}
\hline Variable & Definition & Indicator \\
\hline \multicolumn{3}{|l|}{ Dependent Variable: } \\
\hline \multirow[t]{3}{*}{ Tobin-Q (TQ) } & \multirow{3}{*}{$\begin{array}{l}\text { Ratio to estimate firm value } \\
\text { too high or too low }\end{array}$} & Equity Market Value \\
\hline & & $\overline{\text { Equity Book Value }}$ \\
\hline & & $\begin{array}{l}\text { Assumption: Market value and the } \\
\text { book value of liabilities are the same. }\end{array}$ \\
\hline \multicolumn{3}{|c|}{ Independent Variable: } \\
\hline \multirow[t]{2}{*}{ PS_Institusi } & \multirow{2}{*}{$\begin{array}{l}\text { Ratio to describe ownership } \\
\text { by domestic institutional } \\
\text { shareholders. }\end{array}$} & Domestic Institutional Shareholder \\
\hline & & $\begin{array}{l}\text { Share Issued } \\
\text { The domestic institutional } \\
\text { shareholders include corporate, state, } \\
\text { and cooperative. }\end{array}$ \\
\hline \multicolumn{3}{|l|}{ Control Variables: } \\
\hline Tax Amnesty & $\begin{array}{l}\text { The enacted of tax amnesty } \\
\text { policy in the time data used. }\end{array}$ & $\begin{array}{l}\text { Before enacted the policy }=0, \text { and the } \\
\text { time of enacted the policy }=1 .\end{array}$ \\
\hline Size & $\begin{array}{l}\text { The total asset of the } \\
\text { company }\end{array}$ & Ln(Total Asset) \\
\hline \multirow[t]{2}{*}{ Leverage } & \multirow{2}{*}{$\begin{array}{l}\text { Ratio to describe capital } \\
\text { structure, from liabilities to } \\
\text { assets. }\end{array}$} & Total Liabilities \\
\hline & & Total Assets \\
\hline \multirow{2}{*}{$\begin{array}{l}\text { Earning Per } \\
\text { Share (EPS) }\end{array}$} & \multirow{2}{*}{$\begin{array}{l}\text { Ratio to describe how much } \\
\text { return for each share. }\end{array}$} & Net Income \\
\hline & & $\overline{\text { Share Issued }}$ \\
\hline
\end{tabular}


The population in this study is the manufacturing company listed in Indonesia Stock Exchange as 31 December 2019. There are 137 companies, and the samples are 102 companies. The acquisition of the sampling uses random sampling with Slovin formula and $5 \%$ margin error. The enacted of the tax amnesty was in 2016 and 2017, therefore, the data sampling is 4 years, 2 years before the enacted the policy (2014 nad 2015), and 2 years the time the enacted the policy (2016 and 2017). The total observations in this study are 408 obervations ( $4 \times 102)$.

This article uses 2 regression equations. The first regression is without the tax amnesty policy as a control variable, and the second regrression is with the policy as a control variable. The first regression equation is as follow:

$\mathrm{TQ}_{\mathrm{it}}=\beta_{0}+\beta_{1}$ PS_Institusi $i_{\mathrm{it}}+\beta_{2}$ Size $_{\mathrm{it}}+\beta_{3}$ Leverage $_{\mathrm{it}}+\beta_{4} \mathrm{EPS}_{\mathrm{it}}+\varepsilon_{\mathrm{it}}$

To further examine whether the relationship between the domestic institutional shareholder and the firm value is non linear without tax amnesty as a control variable, the equation (1) is to be a quadratic equation. The equation is:

$\mathrm{TQ} \mathrm{it}_{\mathrm{it}}=\beta_{0}+\beta_{1}$ PS_Institusi $i_{\mathrm{it}}+\beta_{2}\left(\mathrm{PS} \_ \text {Institusi }{ }_{\mathrm{it}}\right)^{2}+\beta_{3}$ Size $_{\mathrm{it}}+\beta_{4}$ Leverage $+\beta_{5} \mathrm{EPS}_{\mathrm{it}}+\varepsilon_{\mathrm{it}}$ (1.a)

The second regression equation is as follow:

$\mathrm{TQ}_{\mathrm{it}}=\beta_{0}+\beta_{1}$ PS_Institusi $_{i \mathrm{it}}+\beta_{2}$ TaxAmnesty $_{\mathrm{it}}+\beta_{3}$ Size $_{\mathrm{it}}+\beta_{4}$ Leverage $_{\mathrm{it}}+\beta_{5}$ EPS $_{\mathrm{it}}+\varepsilon_{\mathrm{it}}$

The quadratic equation of the second regression equation is:

$\mathrm{TQ}_{\mathrm{it}}=\beta_{0}+\beta_{1}$ PS_Institusi $_{\mathrm{it}}+\beta_{2}\left(\mathrm{PS} \text { Institusi }_{\mathrm{it}}\right)^{2}+\beta_{3}$ TaxAmnesty $_{\mathrm{it}}+\beta_{4}$ Size $_{\mathrm{it}}+\beta_{5}$ Leverage + $\beta_{6} \mathrm{EPS}_{\mathrm{it}}+\varepsilon_{\mathrm{it}}$

\section{Result and Discussion}

The statistic descriptive of the variables in this study is in Table 2.

Table 2. Summary Statistics of Variables

\begin{tabular}{lccccc}
\hline \multicolumn{7}{c}{$\mathrm{Tq}$} & Ps_Institusi & Size & Leverage & Eps \\
\hline Mean & 1.567562 & 0.391258 & 14.59611 & 0.186732 & 460.5747 \\
Median & 0.990544 & 0.419274 & 14.32569 & 0.109318 & 28.44000 \\
Maximum & 12.96242 & 0.981786 & 19.50467 & 2.591018 & 38700.47 \\
Minimum & 0.274465 & 0.000000 & 11.51614 & 0.000229 & -17350.39 \\
Std. Dev. & 1.665502 & 0.312332 & 1.564083 & 0.275532 & 3467.585 \\
Skewness & 3.895500 & 0.074802 & 0.595999 & 5.579590 & 8.601617 \\
Kurtosis & 22.31402 & 1.559499 & 3.106555 & 44.00027 & 93.43298 \\
Observations & 408 & 408 & 408 & 408 & 408 \\
\hline
\end{tabular}

Table 2 explains that the data used in this article has very large variations. On average, the market value of the firms is more than their book values, but their median is close to 1 . This 
means that the market value of the firms is almost the same as their book value. There are several firms with the market value far greater than the book value, and this fact can be proven form the maximum value of the firm value (TQ). The share of the domestic institutional shareholders varies greatly, from $0 \%$ to $98 \%$. By using the mean, median, and kurtosis values, it can be concluded that the majority of share ownership by the domestic institutional shareholders is not more than $50 \%$.

The correlation among the variables in this paper is showed in Table 3. Table 3 explains that there is no significant correlation among the variables.

Table 3. Correlation of Variables

\begin{tabular}{|c|c|c|c|c|c|c|}
\hline & $\mathrm{Tq}$ & $\begin{array}{c}\mathrm{Ps} \\
\text { Institusi }\end{array}$ & Size & Leverage & Eps & $\begin{array}{c}\text { Tax } \\
\text { Amnesty }\end{array}$ \\
\hline $\mathrm{Tq} 1$ & 1.000000 & & & & & \\
\hline Ps_Institusi & 0.143275 & 1.000000 & & & & \\
\hline Size & 0.166215 & -0.031626 & 1.000000 & & & \\
\hline Leverage & -0.015822 & -0.011266 & 0.030713 & 1.000000 & & \\
\hline Eps & 0.069252 & -0.101419 & -0.008670 & -0.004459 & 1.000000 & \\
\hline Tax & 0.008093 & 0.058396 & 0.040911 & 0.005458 & 0.000414 & 1.0000 \\
\hline Amnesty & & & & & & 00 \\
\hline
\end{tabular}

The structure data used in this article has more the number of cross section $(\mathrm{N})$ than the number of time series (T). The number of $\mathrm{N}$ is 104 , and the number of $\mathrm{T}$ is 4 . This condition causes the heteroscedasticity in the data [19], and this heteroscedasticity is supported by testing using the e-views program. To reduce this heteroscedasticity effect, a special treatment is needed in running the data. The inter- firm data in this study (cross section data) has a very large in variation and is very volatile. These data characteristics cause very different intercept for each cross section. Therefore, the best model used in this study is fixed effect model. The best regression results of the models in this study are in Table 4.

Table 4. Regressions Results of Domestic Institutional Shareholder on the Firm Value

\begin{tabular}{lrrrr}
\hline \multirow{2}{*}{ Variable } & \multicolumn{4}{c}{ The Firm Value (TQ) } \\
\cline { 2 - 5 } & $(\mathrm{Eq}: 1)$ & $(\mathrm{Eq}: 1 . \mathrm{a})$ & $(\mathrm{Eq}: 2)$ & $(\mathrm{Eq}: 2 . \mathrm{a})$ \\
\hline Intercept & 7.918146 & 8.394999 & 9.178154 & 10.10306 \\
(Prob) & $(0.0000)$ & $(0.0000)$ & $(0.0000)$ & $(0.0000)$ \\
PS_Institusi & 0.180737 & -1.216714 & 0.040666 & -1.213535 \\
$\quad$ (Prob) & $(0.0002)$ & $(0.0034)$ & $(0.5354)$ & $(0.0070)$ \\
(PS_Institusi) $^{\wedge}$ & & 1.422192 & & 1.344072 \\
$\quad$ (Prob) & & $(0.0033)$ & & $(0.0090)$ \\
Tax Amnesty & & & 0.070353 & 0.06963 \\
(Prob) & & & $(0.0000)$ & $(0.0000)$ \\
Size & -0.445669 & -0.465212 & -0.52985 & -0.582274 \\
(Prob) & $(0.0000)$ & $(0.0000)$ & $(0.0000)$ & $(0.0000)$ \\
Leverage & 0.442058 & 0.437229 & 0.380715 & 0.355511 \\
(Prob) & $(0.0000)$ & $(0.0000)$ & $(0.0000)$ & $(0.0000)$ \\
EPS & $2.59 \mathrm{E}-06$ & $2.50 \mathrm{E}-06$ & $2.12 \mathrm{E}-06$ & $1.07 \mathrm{E}-06$ \\
$\quad$ Prob) & $(0.7308)$ & $(0.7358)$ & $(0.7930)$ & $(0.8944)$ \\
\hline R-squared & 0.975122 & 0.97455 & 0.980453 & 0.981791 \\
Adjusted R-squared & 0.966473 & 0.965587 & 0.97357 & 0.975296 \\
Prob(F-statistic) & 0.000000 & 0.000000 & 0.000000 & 0.000000 \\
Durbin-Watson stat & 2.179069 & 2.145017 & 2.212201 & 2.208787 \\
\hline
\end{tabular}


The regression result of equation 1 in Table 4 explains that the domestic institutional shareholders positively and significantly influence the firm value with the constant value 0.181 . This result is consistent with the hypothesis 1 . To discover whether the relationship between the domestic institutional shareholders and the firm value is linear or non-linear, the equation 1.a is calculated its first difference as explained in paper written by Vintilă and Gherghina (2013)[20]. The result of the first difference explains that the relationship between the domestic institutional shareholders and the firm value is non-linear. The relationship changes from positive and significant to be negative and significant after the share ownership more than $42.78 \%$. The calculation of this share ownership as follows:

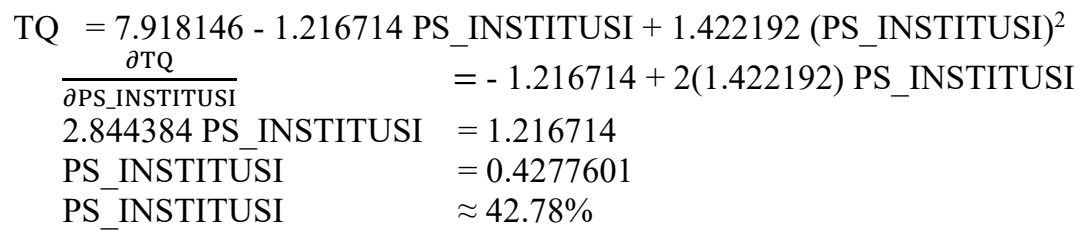

The first difference result is consistent with the hypothesis 1.a. This study explains that the form of relationship between the domestic institutional shareholders and the firm value is nonlinear, inverted U-shaped, and this result is different from the article written by Lozano et.al. (2016). Without the tax amnesty policy as a control variable, the relationship between the domestic institutional shareholders and the firm value is positive and significant when the share ownership is not more than $42.78 \%$. When this relationship becomes negative (share ownership more than $42.78 \%$ ), the purpose of the domestic institutional shareholders is no longer to increase the firm value measured by Tobin $Q$, there may be other objective, such as related party transactions, as explained by Sánchez et. al (2017) [21].

The result of regression equation 2 in Table 4 explains that when the tax amnesty policy used as a control variable in the equation, the relationship between the domestic institutional shareholders and the firm value is positive and not significant. This result differs from the result of regression equation 1 , especially in the significant. The result of regression equation 2 does not support the hypothesis 2 . It can be concluded that with the tax amnesty, the management in the firm undertakes certain strategies whose influence is greater than the influence of shareholders on the value of the company as measured by Tobin Q. This strategy is relevant with Andreoni (1991) explanation [13]. The next question, whether this relationship is linear or non-linear. By calculating the first difference of the regression result of equation 2.a, it is proven that this relationship is non-linear. The relationship between the domestic institutional shareholders and the firm value with the tax amnesty policy as a control variable, changes from positive and not significant to be negative and significant when the share ownership is more than $45.14 \%$. The calculation of this share ownership changes is as follow:

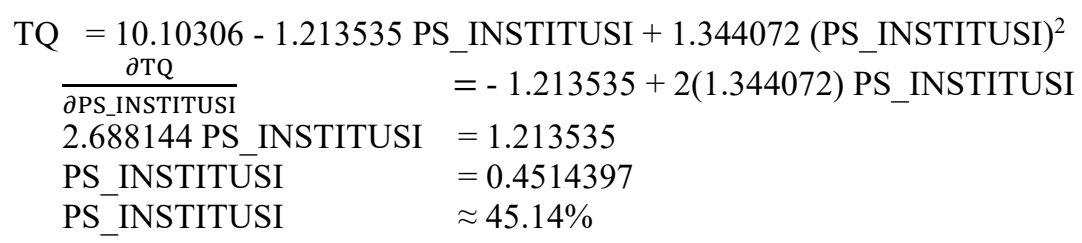


This first difference result is consistent with the hypothesis 2.a. This result indicates that the form of relationship between the domestic institutional shareholders and the firm value with the tax amnesty policy as a control variable is inverted U-shaped, and this form differs from Lozano et.al. (2016) explanation. When the tax amnesty policy is a control variable, the relationship between the domestic institutional shareholders and the firm value is positive and not significant until the share ownership is not more than $45.14 \%$. When this relationship becomes negative and significant (after the share ownership more than $45.14 \%$ ), the goal of the domestic institutional shareholders is not to increase the value of the company.

With or without the tax amnesty policy as a control variable, the relationship between the domestic institutional shareholders and the firm value is non-linear with inverted U-shaped. The most important difference is that the tax amnesty policy, as a control variable, weakens the relationship between the domestic institutional shareholders and the firm value. This difference is proven by the changes of the constant value (from 0.180737 to 0.040666 ), and the changes of probability value (from significant to not significant).

Table 4 explains that the tax amnesty policy positively and significantly influences the firm value. The tax amnesty policy can change or adjust the management strategies, so that it has a positive effect on the firm value. With the existence of this management adjusted strategies, the influence of the domestic institutional shareholders on the firm value changes from significant to insignificant.

\section{Conclusion}

The greater the portion of shares owned by the domestic institutional shareholders, the stronger the effect on the firm value. When the tax amnesty policy is enacted, the influence of the domestic institutional shareholders is getting weaker which can be seen from the changes in the constant to be smaller and in the probability value to be insignificant. The weak influence is estimated by the adjusted strategy implemented by the management as a reaction to the tax amnesty policy. The effect of this adjusted management strategy on the firm value is greater than that of the domestic institutional shareholders on the firm value.

However, the relationship between the domestic institutional shareholders and the firm value is non-linear and inverted U-shaped. When share ownership exceeds a certain amount, shareholders will no longer focus on increasing the value of the company, and it is estimated that this domestic institutional shareholders have other purposes, for example making related parties transaction with the objectives of business expansion.

\section{References}

[1] E. F. Brigham and P. R. Daves, Intermediate Financial Management, Ninth Edit. Ohio, USA: Thomson Higher Education, 2007.

[2] W. He and N. N. A. Kyaw, "Ownership structure and investment decisions of Chinese SOEs," Res. Int. Bus. Financ., vol. 43, pp. 48-57, 2018.

[3] Y. Thanatawee, "Institutional Ownership and Firm Value in Thailand," Asian J. Bus. Account., vol. 7, no. 2, pp. 1-22, 2014.

[4] B. Wang, "Ownership, institutions and firm value: Cross-provincial evidence from China," Res. Int. Bus. Financ., vol. 44, pp. 547-565, 2018. 
[5] M. Du and A. Boateng, "State ownership, institutional effects and value creation in cross-border mergers \& acquisitions by Chinese firms," Int. Bus. Rev., vol. 24, no. 3, pp. 430-442, 2015.

[6] J. Song, R. Wang, and S. T. Cavusgil, "State ownership and market orientation in China's public firms: An agency theory perspective," Int. Bus. Rev., vol. 24, no. 4, pp. 690-699, 2015.

[7] M. Jafarinejad, S. R. Jory, and T. N. Ngo, "The effects of institutional ownership on the value and risk of diversified firms," Int. Rev. Financ. Anal., vol. 40, pp. 207-219, 2015.

[8] P. A. Gompers, J. L. Ishii, and A. Metrick, "Financial Institutions Corporate Governance and Equity Prices," J. Econ., 2003.

[9] B. Buchanan, C. X. Cao, and C. Chen, "Corporate social responsibility, firm value, and influential institutional ownership," J. Corp. Financ., vol. 52, no. 2018, pp. 73-95, 2018.

[10] M. B. Lozano, B. Martínez, and J. Pindado, "Corporate governance, ownership and firm value: Drivers of ownership as a good corporate governance mechanism," Int. Bus. Rev., vol. 25, no. 6, pp. 1333-1343, 2016.

[11] R. Bayer, H. Oberhofer, and H. Winner, "The occurrence of tax amnesties: Theory and evidence 放," J. Public Econ., vol. 125, pp. 70-82, 2015.

[12] A. Pratama, "Analysis of Tax Amnesty Disclosures, Tax Avoidance, and Firm Value," Indones. J. Contemp. Account. Res., vol. 1, no. 1, p. 21, 2019.

[13] J. Andreoni, "The desirability of a permanent tax amnesty," J. Public Econ., vol. 45, no. 2, pp. $143-159,1991$.

[14] A. M. O. Gharaibeh and A. A. A. A. Qader, "Factors influencing firm value as measured by the Tobin's Q: Empirical evidence from the Saudi Stock Exchange (TADAWUL)," Int. J. Appl. Bus. Econ. Res., vol. 15, no. 6, pp. 333-358, 2017.

[15] H. C. Kang, R. M. Anderson, K. S. Eom, and S. K. Kang, "Controlling shareholders' value, long-run firm value and short-term performance," J. Corp. Financ., vol. 43, pp. 340-353, 2017.

[16] B. C. Ayers, A. C. Call, and C. M. Schwab, "Do Analysts' Cash Flow Forecasts Encourage Managers to Improve the Firm's Cash Flows? Evidence from Tax Planning," Contemp. Account. Res., 2018.

[17] J. K. Klassen, P. Lisowsky, and D. Mescall, "The role of auditors, non-auditors, and internal tax departments in corporate tax aggressiveness," Account. Rev., vol. 91, no. 1, pp. 179-205, 2016.

[18] K. Balakrishnan, J. Blouin, and W. Guay, "Tax Aggressiveness and Corporate Transparency," Account. Rev., 2017.

[19] D. N. Gujarati, Basic Econometrics, Fourth Edi. New York: McGraw-HiII/lrwin, 2003.

[20] G. Vintilă and Ş. C. Gherghina, "Board of Directors Independence and Firm Value : Empirical Evidence Based on the Bucharest Stock Exchange Listed Companies," Int. J. Econ. Financ. Issues, vol. 3, no. 4, pp. 885-900, 2013.

[21] C. Bona-Sánchez, C. L. Fernández-Senra, and J. Pérez-Alemán, "Related-party transactions, dominant owners and firm value," BRQ Bus. Res. Q., vol. 20, no. 1, pp. 4-17, 2017. 